Chapman University

Chapman University Digital Commons

Education Faculty Articles and Research

College of Educational Studies

2013

\title{
Family Portraits: Past and Present Representations of Parents in Special Education Text Books
}

Dianne L. Ferguson

Chapman University,dferguso@chapman.edu

Philip M. Ferguson

Chapman University, pferguson@chapman.edu

Joanne Kim

Chapman University

Corrine Li

Chapman University

Follow this and additional works at: http://digitalcommons.chapman.edu/education_articles

Part of the Disability and Equity in Education Commons, Family, Life Course, and Society Commons, and the Special Education and Teaching Commons

\section{Recommended Citation}

Ferguson, D. L., Ferguson, P. M., Kim, J. \& Li, C. (2013). Family portraits: Past and present representations of parents in special education textbooks. International Journal of Inclusive Education, 17(12), 1326-1341. DOI: 10.1080/13603116.2013.826293

This Article is brought to you for free and open access by the College of Educational Studies at Chapman University Digital Commons. It has been accepted for inclusion in Education Faculty Articles and Research by an authorized administrator of Chapman University Digital Commons. For more

information, please contact laughtin@chapman.edu. 


\section{Family Portraits: Past and Present Representations of Parents in Special Education Text Books}

\section{Comments}

This is an Accepted Manuscript of an article published in International Journal of Inclusive Education, volume 17 , issue 12, in 2013, available online: DOI: 10.1080/13603116.2013.826293

\section{Copyright}

Taylor \& Francis 
Family Portraits:

Past and Present Representations of Parents in Special Education Text Books

Dianne L. Ferguson, Ph.D, Philip M. Ferguson, Ph.D.,

Joanne Kim, M.A. and Corrine Li, M.A., CCC-SLP

College of Educational Studies

Chapman University

All communication about this manuscript should be directed to: dferguson@chapman.edu 


\begin{abstract}
This paper analyzes the descriptions of families of children with disabilities as contained in introductory special education texts over the last 50 years. These text books are typically used in preservice teacher education courses as surveys of the education of "exceptional children." The textbooks reflect the mainstream professional assumptions of the era about topics such as disability, special education, inclusion, and family/school linkages. However, they also shape the assumptions of the next generation of educators about these same topics. The paper summarizes the results of a qualitative document analysis of a sample of these textbooks from two different eras. The paper compares and contrasts how the representations of families by leading scholars in special education have changed over time.
\end{abstract}


As Ellen Brantlinger (1997) so usefully explained in her analysis of the "traditionalist" critiques of inclusion, ideology is most dependably present when it is being denounced in others. In a neutral sense, ideologies are simply "systems of representations (images, myths, ideas) which, in profoundly unconscious ways, mediate one's understanding of the world (Brantlinger, 1997, p. 438). In short, ideology is everywhere. It is the standpoint from which we perceive the world; the discursive assumptions from which we interpret what we see. What makes the analysis of ideology important, then, is not to discover its presence; it is always present. What is useful (and this is the power of much of Brantlinger's work) is to reveal its influence on those who disavow any ideological component to their work. This study follows Brantlinger's lead by analyzing the underlying ideological frames that can be found in one of the most ubiquitous but under-analyzed settings for the representation of special education knowledge: the large, introductory texts used in almost every teacher education program in the United States (and elsewhere).

Not only is ideology everywhere; so are the "big glossies." To borrow Ellen Brantlinger's (2006) wonderful term, the "big glossies" are the introductory textbooks churned out by the handful of publishing conglomerates that increasingly dominate the market. Almost everyone connected to teacher education is familiar with them. As students in teacher education programs, almost all of us took at least one course that was organized around one of these texts. As instructors, many of us have felt immense pressure to use one of these texts in a course. Others of us have contributed chapters to edited collections that seem to require revision for a new edition every other year. Of course, those new editions arrive free of charge in our mailboxes. Now they come packaged with their own websites, testing resources, and links to online instructor assistance. In the near future, the expectation is that 
these books will become almost entirely web-based. They are, truly, an omnipresent feature of teacher education and have been for over 50 years.

Within special education teacher preparation programs in the United States, the most common place to find a "big glossy" in use is as the main required textbook for the introductory course. That course goes by many names, but it is usually some variant of "Introduction to Exceptional Learners." Coincidentally, that description also applies to the titles of the books seeking adoption for use in those courses. In traditional teacher preparation programs, this course may be the only one required for preservice general educators where disability issues are discussed at length. For those preparing for careers in special education, it is the initial framework for their gradual induction into the professional context of teaching children with disabilities. In short, these books have played what would seem to be an immensely important role in shaping the underlying assumptions, beliefs, and expectations of generations of general and special education teachers about how we should support children with disabilities and their families.

Despite this prominence, the special education textbooks have received relatively little critical analysis from what might be called a disability studies perspective. As already mentioned, an important exception to this is Ellen Brantlinger's careful analysis of "The big glossies: How textbooks structure (special) education" (2006). Brantlinger's work focused on how the books she examined construct disability itself. Within a powerful review of how corporations work to control the discourse of teacher preparation, she asked whether and how the books discuss structural issues of systemic inequity; how they frame issues of race and class; and whether inclusive instructional approaches are discussed. She tied her analysis to the work of more familiar critics within a general education context (e.g. Apple, 1989; Apple \& Christian-Smith, 1991; Kohn, 2003). 
In many ways, we see these textbooks as "lagging indicators" of the paradigm shift in disability studies and special education. They will be the last to change because of an institutional conservatism built into the process of teacher preparation and course book design. As Brantlinger persuasively argues, the content of these texts is, to a great extent, governed by the economics of book publishing (Brantlinger, 2006, p. 51). The books must be adopted for use in courses or they will not stay in print. The market forces, then, push textbook authors to "pitch" their textbooks to appeal to the largest possible audience, which means changed content in texts can be expected to change only after those changes have made their way into the policies and practices of teachers and students. The introductory courses at which they are aimed are, in turn, designed to address the official standards of knowledge and skill presented by both professional organizations such as the Council for Exceptional Children and by the teacher credentialing agencies of the various states. While improvement in these official standards of professional "expertise" should be noted, they nonetheless continue to be imbued with the assumptions of individual deficits, behavioral assessment and instruction, and placement continuums. Given this, then a review of how much (or how little) the content of these textbooks has changed over time can serve as a rough measure of how thorough-going has been the shift to more social models of disability with the corollaries of family partnerships and community inclusion.

One important area of content that Brantlinger did not focus on is how the introductory textbooks frame and discuss the families of the children with disabilities. This is where our study picks up ${ }^{\mathrm{i}}$. In addition, we were interested in whether and how the discussion of families within these textbooks had changed over time. This study is also part of a larger analysis that we are doing that explores more generally the personal and professional portrayal of families as it has evolved over the last century or so (Ferguson, D.L. \& Ferguson, P.M., 2010; Ferguson, P.M., 2008; Ferguson, P. M. \& Ferguson, D. L. 2006). Specifically, we asked the following questions: 
1. How do textbooks designed for introductory courses in pre-service special education programs portray parents/families of children with disabilities?

2. How do the textbooks describe and discuss family/school linkages?

3. How have the portrayals and descriptions contained in these textbooks changed over time?

\section{Methodological Approach}

To answer these questions, we used conventional methods of qualitative document analysis located within an interpretivist research tradition (Bogdan \& Biklen, 2007; Ferguson, Ferguson, \& Taylor, 1992; Rossman \& Rallis, 2003). We used a purposefully chosen sample of 14 textbooks as the source documents for analysis. The list of selected books is included in Table 1 . The books are also starred $\left({ }^{*}\right)$ in the reference list at the end of the paper. We chose the textbooks according to criteria designed to produce a representative cross-section of the most-used texts of their respective eras. These criteria included:

- Date of publication: The study included books published between roughly 1960 and 2012 with seven of the books coming from before 2000 and seven coming after 2000.

- Publisher: We emphasized books published by the larger, more influential publishers in the United States of education texts (e.g., Houghton-Mifflin, Little/Brown, Pearson/Merrill/Prentice Hall, Cengage/Wadsworth, McGraw-Hill).

- Longevity: The study also emphasized books that have had multiple editions, with longevity inferred to be a marker of popularity in courses. For example, the text by Samuel Kirk (1962) -and the additional authors added in later editions -- has gone through 13 editions and has been a standard, introductory text for some 50 years. 
- Focus: While most of the textbooks that we selected cover the full range of "exceptionality," we also included a few texts that focus on specific categories of disability. Partly, this reflects the emphasis of the eras. In the 1960s and 1970s, some of the most influential textbooks (e.g., Chinn, Drew, \& Logan, 1975) focused on "mental retardation," although this label included many children who would have different (or perhaps no) labels in today's schools. This also allows some additional comparisons between descriptions of families across specific categories of disability (e.g., are families of children identified as learning disabled portrayed differently than families of children identified and intellectually disabled?).

For our analysis, we used a process of systematic but flexible document analysis. All passages containing more than passing references to parents and other family members of children with disabilities were identified for coding. We used both a more analytic approach associated with grounded theory as well as a comparative process that used themes of discourse that we had already identified in some of our earlier work. We coded the individual passages and then used a more wholistic comparison to the earlier themes for family linkage discourse. After one of us had identified and coded passages from one of the books, the others would review those passages in a version of peer debriefing (Marshall \& Rossman, 2006). Finally, we did an additional analysis of all the "call outs" that first began appearing in 1989. These are the passages that are "boxed off" from the regular text, and often include photos and other information, some focused on family or personal narratives. We analyzed the content that included mention or focus on families first and then completed a second more wholistic look at the messages of all the call outs and photos. The final stages of wholistic comparison and thematic summary and interpretation were done together. 


\section{Discourses of Family Involvement}

Following the coding of individual passages, we added a second stage of analysis where we compared our findings to our earlier research that has described three broad categories of rhetoric and policy in educational approaches to family/school linkages (Ferguson, D., Hanreddy \& Ferguson, P., in press). This earlier analysis emerged from our analysis of both scholarly work on family/school linkages and the language used by teachers and administrators with whom we have worked over the years. We have labeled the three approaches or rhetorics of family involvement as (1) rights-based, (2) educational benefits, and (3) social justice/equity. One outcome of this new study has been to evaluate how well these previous themes work in summarizing the content of both past and present textbooks. Obviously, in using this two-stage approach to the analysis of our data, we needed to critically reflect on how our earlier findings might unduly influence our analysis in the current study. However, we feel that the traditional techniques of surfacing and bracketing assumptions allowed us to benefit from this previous research while remaining open to revision and contrast. The three family discourses, then, served as a frame on which we can build our current analysis rather than imprison it.

Before turning to our results, it may be useful to review the three discourses used by scholars and special education professionals to talk about families of children with disabilities. Each of these has its strengths, but each, as well, can definitely be problematic. Our argument about these discourses has two basic points. First, the very existence of the different discourses and how they explain and justify family involvement is important to notice. Otherwise, the hidden assumptions or alternative interpretations may be overlooked. Second, once we start paying attention to the various discourses, it quickly becomes clear that the social justice/social relations approach remains largely on the fringes of the dominant views in special education. 
The rights-based approach, in an American context, is best exemplified by a focus on the requirements of Individuals with Disabilities Education Act (IDEA). Within that federal legislation governing special education, there is a range of legal requirements that schools "have to" do in order to be in compliance with the law. This approach will often describe the rise of parent activism and disability advocacy as keys to the current status of family involvement. Yet within this approach the desired outcome of genuine partnership between school personnel and families in providing educational support to students with special educational needs all too often proceeds with only minimal (or even no) contribution from families, or deteriorates into a series of formalistic procedures or even adversarial relationships. The current "sign off" practices in many American schools of "parent compacts" in order to meet the requirements for family involvement or the practice of having an IEP already prepared by the professionals for the IEP meeting (with the expectation that family members will simply sign off) are examples of the perfunctory type of family involvement. In many ways, this discourse about families is what Brantlinger refers to as a "legalistic" model of disability (Brantlinger, 2006, p. 52). Perhaps the most familiar example of the adversarial style occurs when the legalistic elements of due process hearings overtake the IEP procedures.

A second type of family-involvement discourse might be called an educational benefits approach. This approach is one that most schools use to decide how to engage families whether or not the child has a disability. This approach is less dominated by an emphasis on procedural requirements and, instead, uses a type of cost-benefit analysis. That is, will the activity - whatever it is - result in some amount of educational benefit that is "worth" the cost of engaging in the activity in the first place? Will it result in families assisting the school to teach the students in some way? By bringing in additional resources, by directly helping teachers prepare and deliver instruction, or by extending learning activities past the school day, into the evenings and weekends. These activities or offerings are often things that schools can do without too much cost in terms of energy, time, or resources while still obtaining the benefit to 
the school, teacher, or the student in terms of improved learning achievement. There are both positive and negative versions of this discourse. On the positive side, the approach tends to see at least some families as resources who can help the school and extend the school agenda. But only some families are seen as resources by school personnel. On the negative side, then, certain families are seen as needing "work" in the form of instruction and training on how to parent and how to support the school agenda (Harry, Kalyanpur, \& Day, 1999; Lareau, 2005; Lightfoot, 2004). Unfortunately, this last group can sometimes seem to "cost" more than schools receive in benefit. In the end family activities in this approach can end up being either haphazard or ritualistic. The occasional efforts to reach out to families or the occasional family training event are examples of the first, while parent/teacher conferences and "family nights" can all too often be stale examples of the second.

There is a third approach, although it is only addressed by a relatively small number of schools and scholars in special education (Brantlinger, 1993; 2003; Harry, Kalyanpur, \& Day, 1999; Lopez, Scribner, \& Mahitivanichcha, 2001). This social relations/social justice approach is one that requires school personnel to first understand the issues embedded in our cultural, socioeconomic and other forms of human diversity and then to use this understanding to "filter" all efforts toward families in order to better reach and engage all of those families. As Brantlinger put it in her powerful analysis of how schools embody and perpetuate the same hierarchical inequities found in the larger society,

Unless the desires and intentionality behind advantage and the negotiations of the winners in stratified schools are examined and confronted, school reform that is (purportedly) aimed at increasing equity will never succeed. ... As long as the lay public, policy makers, school managers, and educational scholars locate the problem in school losers and direct their efforts at changing them, a dent will not be put in the ubiquitous class-biased practices in school. (Brantlinger, 2003, p. 192) 
Despite their scarcity, specific examples can be found of efforts to overcome the inequities faced by students and their families within both general and special education contexts, from large policy commitments to small acts of daily practice. Making sure that all school communication (not just those documents required by law) is translated into a family's first language is one obvious, but often very difficult, example of this kind of outreach and honoring of students' families (Ferguson \& Galindo, 2008). Building teachers' capacity to understand, appreciate, and take into account issues of differing social/cultural capital, family lifestyles, socioeconomic advantages and needs, as well as families "funds of knowledge" (Gonzalez, Moll, \& Amanti, 2005; Moll \& Greenberg, 1990) is required to fully employ a social relations/social justice approach in such a way that truly inclusive and democratic school communities that successfully engage all families in students' learning and achievement. This approach, however, is often too hard and time consuming, especially in terms of the capacity building required of school personnel to be more than rhetoric in most schools, if it even rises to that level of awareness. Even schools that make good faith efforts in this area find it difficult to maintain such efforts over time or expand to accommodate new populations of families as student demographics change.

\section{Results}

Certainly these textbooks reveal that the attention afforded families has both grown and changed over the last 50 years. However, as is often the case, the devil is in the details. In this section, we will provide both a summative and interpretive analysis of what we found in our readings of the 'big glossies'. A list of books reviewed is provided in Table 1 . The books are organized first by publication date with the exception that multiple editions of two of the most prominent textbooks (six editions of the "Kirk" textbook and three editions of the "Hallahan and Kauffman" textbook) are grouped together for easier comparison. 
In addition to the publication dates, Table 1 summarizes several types of information. Although our primary focus when analyzing these texts was what was said about families more than what was said about disabilities, there is an obvious overlap. So, following Brantlinger's example (Brantlinger, 2006), we have identified the "disability discourse" used by each book. By this, we are primarily describing whether the text employed a categorical approach or not, organizing its contents around chapters separately devoted to specific categories of disability. As Brantlinger described in her analysis of the big glossies, the politics of publishing make it difficult for textbook authors to use anything but the traditionalist, categorical approach where "each disability category or disabling condition was outlined as including students who were clearly distinctive from students with other types of disabilities and students without disabilities" (Brantlinger, 2006, p. 52). As can be seen by Table 1, at least for our sample of books, the categorical approach remains the dominant one. (There are a few introductory texts that have tried to buck this categorical approach, for example Sands, Kozleski, and French, 2000, but they remain the exception rather than the rule.)

The table also presents a summary of whether the text has a separate chapter explicitly addressing family or family/school issues. Of course, this information by itself is little more than suggestive. It provides no information about the content of that separate chapter, should it exist. It says nothing about how much discussion of families is provided in other parts of the text. Still, it seemed to provide a rough indication of one of the basic changes that we noticed in comparing older versus newer textbooks. The attention given to family issues has undeniably increased.

Finally, Table 1 also summarizes our overall assessment of whether and how prominent the three family discourses that we have already discussed were in each of the texts. For each book in our sample we assigned a level of prominence for each of the family discourses: primary (P), secondary (S), incidental (I). If we found no evidence of a particular discourse, we used a "not found" label (NF). Our 
basis for these summative characterizations for what could be - especially in a few of the most recent textbooks - a complicated variety of comments about families, was obviously impressionistic. However, the characterizations emerged from joint discussions following our independent review and coding of each text. We did develop one "bright line" test for the assessment of "social justice" discourse. After much discussion, we decided that it was essentially contradictory to say that a textbook organized around a categorical approach to disability used social justice as its "primary" discursive approach. At best, such books used social justice in a significant but secondary manner.

A final important distinction used in the table involves the two strands of educational benefits discourse that emerged as one of the clearest distinctions between the older textbooks and the more recent ones. As we will discuss at more length later, what little attention the earliest texts gave to families was largely negative in tone and emphasis. The "benefit" that children received from educational involvement with parents was of a preventive nature: it could minimize or reverse the negative influences that neurotic, grief-stricken, over-protective or rejecting parents inflicted on their children. This version of the educational benefits discourse contrasts with the more recent rhetoric that is - at least on the surface - predominantly positive in tone and emphasis. Families (no longer just parents) in these texts are seen as resources for the school to draw upon. Families are important teammembers, partners, and collaborators who can further the work of educators to the positive educational benefit of the children. Finally, some texts had roughly equal amounts of both positive and negative benefits language. So, in Table 1, when Educational Benefits language was found, we added a further description as "Negative" (NEG), "Positive" (POS) or “Mixed" (Mixed). 
Table 1: Textbooks Reviewed by Publication Date and Content Analysis

\begin{tabular}{|c|c|c|c|c|c|c|}
\hline \multirow[b]{2}{*}{ PUB (ED.) } & \multirow[b]{2}{*}{$\frac{\underline{\text { PUB }}}{\underline{\text { DATE }}}$} & \multirow[b]{2}{*}{$\begin{array}{l}\text { DISABILITY } \\
\text { APPROACH }\end{array}$} & \multirow[b]{2}{*}{$\begin{array}{l}\text { SEPARATE } \\
\text { FAMILY CHAP }\end{array}$} & \multicolumn{3}{|c|}{ FAMILY DISCOURSE APPROACH } \\
\hline & & & & $\begin{array}{l}\text { EDUC. } \\
\text { BENEFITS }\end{array}$ & $\begin{array}{l}\text { PARENT } \\
\text { RIGHTS }\end{array}$ & $\begin{array}{l}\text { SOCIAL } \\
\text { JUSTICE }\end{array}$ \\
\hline Kirk $\left(1^{\text {st }}\right)$ & 1962 & Categorical & No & I (Neg) & NF & NF \\
\hline $\operatorname{Kirk}\left(2^{\text {nd }}\right)$ & 1972 & Categorical & No & I (Neg) & NF & NF \\
\hline $\begin{array}{l}\text { Kirk/Gallagher } \\
\left(3^{\text {rd }}\right)\end{array}$ & 1979 & Categorical & No & I(Mixed) & $S$ & I \\
\hline $\begin{array}{l}\text { Kirk/Gallagher } \\
\left(6^{\text {th }}\right)\end{array}$ & 1989 & Categorical & No & P(Mixed) & $S$ & I \\
\hline $\begin{array}{l}\text { Kirk/Gallagher/ } \\
\text { Anastasiow }\left(8^{\text {th }}\right)\end{array}$ & 1997 & Categorical & No & P (Mixed) & $S$ & I \\
\hline $\begin{array}{l}\text { Kirk/Gallagher } \\
\text { Coleman/ } \\
\text { Anastasiow } \\
\left(13^{\text {th }}\right)\end{array}$ & 2012 & Categorical & Yes & P (Pos) & $S$ & I \\
\hline $\begin{array}{l}\text { Smith/ } \\
\text { Neisworth }\end{array}$ & 1975 & Functional & $\begin{array}{l}\text { Yes (Family } \\
\text { Probs) }\end{array}$ & $P$ & & \\
\hline $\begin{array}{l}\text { Hallahan/ } \\
\text { Kauffman }\end{array}$ & 1978 & Categorical & No & I (Neg) & & \\
\hline $\begin{array}{l}\text { Hallahan/ } \\
\text { Kauffman }\left(9^{\text {th }}\right)\end{array}$ & 2003 & Categorical & Yes & $P$ & $S$ & NA \\
\hline $\begin{array}{l}\text { Hallahan/ } \\
\text { Kauffman/ } \\
\text { Pullen }\left(12^{\text {th }}\right)\end{array}$ & 2012 & Categorical & Yes & $\mathrm{P}$ (Pos) & S & I \\
\hline
\end{tabular}




\begin{tabular}{|l|l|l|r|l|l|l|}
\hline Friend $\left(3^{\text {rd }}\right)$ & 2011 & Categorical & $\begin{array}{c}\text { No } \\
\text { (but section in } \\
\text { each chap) }\end{array}$ & P (Pos) & I & S \\
\hline Heward $\left(9^{\text {th }}\right)$ & 2009 & Categorical & Yes & P (Pos) & S & I \\
\hline $\begin{array}{l}\text { Turnbull/ } \\
\text { Turnbull/ } \\
\begin{array}{l}\text { Wehmeyer (6 } \\
\text { th }\end{array}\end{array}$ & 2010 & Categorical & Yes & P (Pos) & S & I \\
\hline $\begin{array}{l}\text { Rosenberg/ } \\
\text { Westling/ } \\
\text { McLeskey (2 }\end{array}$ & 2011 & Categorical & No & P (Pos) & I & NA \\
\hline
\end{tabular}

\begin{tabular}{|c|c|}
\hline$S=$ Secondary & NA $=$ Missing/Absent \\
\hline POS = Positive Educational Benefits & NEG $=$ Negative Educational Benefits \\
\hline
\end{tabular}

\section{"Simple" Quantity}

Certainly, over time, the amount that has been said about families in these introductory textbooks has noticeably grown. There is a progress from fewer than 10 instances where parents were mentioned in the earlier texts to a fairly consistent pattern of a single chapter devoted to families, their experiences and their role in the education of their child with disabilities beginning about 1990. In between mere mentions of parents or families grew gradually to a couple of pages, then 15 pages until the separate chapters began which range in length from $25-30$ pages. Usually these pages took the form of a short section on families or parents in some, but not all chapters. Only one of our more recent texts (Friend, 2011) departed from the chapter approach in favor of a section in every chapter with the heading "Parent and Family Perspectives." But the choice of a single chapter in the other examples explored here- with a few important exceptions (Turnbull, Turnbull \& Wehmeyer, 2010) - usually meant that few 
other mentions of families were included in other chapters. A few of the later texts offer vignettes written by family members or persons with disabilities, but in the case of family/parent narratives the focus typically emphasizes the "educational benefits" discourse.

Over time then these authors of introductory textbooks have paid more attention to families and that attention has become more positive overall. However, the attention afforded families and their role in the education of their children still only represents a tiny proportion of the material in these texts. Most of the texts run a little over 400 pages. A few run closer to 500 , and one nearly 600 , but when all mention of families whether in a separate chapter or in sections scattered throughout the book is taken together it only amounts to $3-5 \%$ of the material in the text.

One could argue, of course, that families are not the focus of such introductory texts and that there are certainly separate texts devoted to the experiences and roles of families in the lives of children and adults with disabilities (e.g., Turnbull, Turnbull, Erwin, Soodak, \& Shogren, 2010). Yet in education more broadly there is a growing conversation about the critical importance of family/school linkages to not only improve learning and achievement outcomes for children and youth (e.g.,Ferguson, C., Ramos, M., Rudo, Z., \& Wood, L. 2008; Henderson \& Mapp, 2002) but also an increasing focus on the need to shift the discourse from "family involvement" [in schools] characterized by the dominant "educational benefits" discourse to a discourse of family/school linkages that is meant to benefit not only student learning outcomes and assist educators in better "do their jobs", but also to benefit the family and the community in ways that strengthen family and community ties, foster social justice, and contribute to socially just communities (eg., Kalyanpur, Harry \& Skrtic, 2000; Rao, 2000). As other parts of education pursue this discussion, it seems the special education community could benefit from joining the conversation as well - at least in terms of attention paid in introductory textbooks (Brantlinger, 2003; 2010). 
In a similar way, while the use of various types of "call-outs" began modestly with just a few different examples (e.g., focusing questions for the chapter, chapter summaries). Soon this feature was commonly used to present brief vignettes or narratives, some of which focused on families. However, the use of call outs expanded rapidly so that by late 1990s in addition to vignettes, they reference, for example, Council for Exceptional Children (CES) standards, resources of various types, educational strategies, websites, resources, key concepts, misconceptions and moral dilemmas. With the most recent examples in our sample, the use of call outs continues to expand with more content-directed items including practice tips, technology outcomes, partnership tips in addition to "My Voice" narratives. So even here family focused call-outs or narratives of youth or adults with disabilities only represent a small proportion of the content offered in this "boxed off" or "set apart" way.

\section{Not-So-Simple Quality}

Our analysis tried to move beyond a simple quantitative content analysis of the texts. Our overall purpose was to see whether the discursive approaches had evolved as well. Certainly, much has changed over the last 50 years in the how leading scholars portray the families of children with disabilities in books aimed at training the next generation of special educators. As we have mentioned, in the earlier textbooks, families were largely absent. However, even more striking is that when families were mentioned, it was usually to describe the problems they presented to professionals. In the first edition of his classic introductory textbook, Educating Exceptional Children, Samuel Kirk (1962), describes the goal of parent volunteers for special education classrooms as misguided: "Parents of severely retarded children do not generally succeed [as helpers] in classes in which their own child is enrolled" (p. 141). Indeed, for Kirk, the main goal of teachers in terms of parents is to respond to and control the problems they create. Parents of blind children tend to "overprotect" -- governed as they are by "guilt, hostility, anxiety, or simply lack of knowledge" (p. 223). The attitudes of parents of "crippled children ... whether rejecting or overprotecting, tend to be more extreme than their attitudes 
toward normal children" (p. 287). Even by 1975, a similar introductory volume (from a major publisher of education texts) was still explaining why mothers were often more problematic than fathers: "It is the mother who 'produces' the infant, it is she who 'gives' it birth. If the 'product' turns out to be defective, the mother is likely to perceive this as a defect in something she has labored to produce" (Smith \& Neisworth, 1975, p. 181). Fortunately, this type of psychoanalytic "mother-blaming" is much less common today - at least in such blatant terms.

In response to the supposed symptoms and neuroses presented by parents, prospective teachers are told to notice and compensate for the mistakes made at home. In both the first and second editions of his text, Kirk recommends that teachers practice something he calls the "scientific neglect" of children who have been overprotected and attended to by parents (Kirk, 1962, p. 290; Kirk, 1972, p. 377). Another early text (Smith \& Neisworth, 1975) recommends "periodic" conferences with parents. However, the purpose of the conferences seems primarily to diagnose the specific problems they present. "As a result of the conference, and any information you have available, estimate the parents' competence in working with you. Are they naïve, misinformed, pushy, prone to compare the child with siblings, apparently incapable of following a supplementary program of any complexity, or too demanding of the child" (p. 215).

\section{Evolution of the Discourse}

In the years immediately following 1975 and the passage of Education of All Handicapped Children Act, there is some noticeable change in both the tone and the content of the textbooks. It is interesting to follow these changes as they occur through various editions of a single textbook. For the Third Edition of his successful book, Samuel Kirk had James Gallagher join him as a co-author. Gallagher's influence can be seen especially in the discussion of parents. An entirely new section of a chapter on future 
directions in special education focuses on the "Changing Role of Parents." The section is organized around four proposed stages through which parents have struggled to gain their proper place.

The parents have gone through a number of phases and roles which may be referred to as: (1) parents as scapegoats, (2) parents as program organizers, (3) parents as political activists, and (4) parents as program participants and partners. (Kirk \& Gallagher, 1979, p. 467)

The authors go on to claim that general progress has been made in overcoming the past tendencies to blame parents unfairly. They approvingly quote another text as a sign of the changed perspective:

Have we as professionals working in a field that traditionally has been child-centered unwittingly cast parents into the role of adversary, object of pity, inhibitor of growth, or automatic misfit, while expecting them to perform in a way expected of no other parents? Have we been too quick to focus on weakness and too slow to recognize the normality of the behaviors we see? (Cansler, Martin, \& Valand, 1975, as cited in Kirk \& Gallagher, 1979, p. 468)

With the publication of the sixth edition of the book in 1989, this earlier section was gone. Replacing it, however, is a total of 12 pages at the beginning of the book that continues to assert that the "tendency to set parents up as scapegoats has changed" (K \& G, p. 20). The new section covers an impressive range of issues, including in the influence of family life cycles, influences on stress and coping, and even a few paragraphs on siblings. A long story about Ed Roberts and the emergence of the independent living movement is integrated within the family material, capturing the sense of advocacy and political activism that had emerged over the past two decades. By the $8^{\text {th }}$ edition in 1997 , there is language added about "parent empowerment," and parents as "team members" (Kirk, Gallagher, \& 
Anastasiow, 1997, p. 30). The shift is also beginning here to talk about families more than parents. The changing demographics of family structure are discussed in fairly neutral terms: more single-parent households, more dual-career families, more recognition of fathers as part of thecare-giving equation. A chart in the book details how instead of training mothers to become essentially home-based paraprofessionals, the "current approach" asserts that

Families need encouragement and ways to ensure that the child has a functional education taught in natural environments by natural helpers in those environments (e.g, family friends, store clerks, busdrivers, scout leaders). (Gartner, Lipsky, \& Turnbull as cited in Kirk, Gallagher, \& Anastasiow, 1997, p. 31).

Over the same period of these striking changes in tone and content, the Kirk et al., books continued to use the traditional list of psycho-analytic categories to characterize the response of "most parents" to the birth of a child with disabilities. Parent of children with disabilities are still seen as dramatically different from other families, "reifying" (Brantlinger, 1997, p. 440) the difference and "naturalizing" the response in the same way that segregated special education is traditionally justified. The parent is still described as having to overcome the "symbolic death of the child who was to be" (p. 17). Upon hearing their child's diagnosis, "most parents feel shock, then denial, guilt, anger, and sadness, before they finally adjust ... Many move through the grieving process, as though their child had died." (p. 20). In another major textbook that was first published in 1978 (Hallahan \& Kauffman, 1978), there is a similar assessment of parental emotions. Having a retarded (sic) child is said to evoke feelings of "honest agony, hatred, sorrow, and frustration" (p. 60). 
Rights-Based Discourse

We were somewhat surprised with the relatively small amount of what we would clearly identify as "rights-based" language in the discussion of families in the more recent textbooks. The textbooks published in the late 1970s showed an understandable emphasis in this area. However, in textbooks from the last 5 years, we found very little about legal process laying out the requirements for parent involvement. Instead, we found most of the conversation in recent texts using language and concepts that we associate with the "educational benefits" approach. The Heward text (2009) provides a typical example of this:

Extensive evidence shows that the effectiveness of educational programs for children with disabilities is increased when parents and families are actively involved .... At the very least, teachers and students benefit when parents provide information about their children's use of specific skills outside the classroom. But parents can do much more than just report on behavior change. They can provide extra skill practice and teach their children new skills in the home and community. When parents are involved in identifying what skills their children need to learn ... the hard work expended by teachers is more likely to produce outcomes with real significance in the lives of children and their families. (Heward, 2009, p. 92)

Heward does go on to spend several paragraphs on the "mandating parent and family involvement" steps that Congress placed in the earliest version of IDEA (rights-based). However, the overall tone of the book is that teachers and schools should encourage parents to be involved in because it produces improved outcomes for children. 
Another example of this approach can be found in the recent text by Rosenberg, Westling, and McLeskey (2011). While the book breaks the pattern of most recent texts and does not include a selfcontained chapter on families, it does have short discussions of specific issues that may arise in family/school interactions. The discussions emphasize the cost-benefit calculation that many schools implicitly employ when considering family involvement: how should teachers respond to families that "want more than you can offer" (p. 394)? The recommendation in such situations is to evaluate and respond cautiously after adding up costs and benefits. When parents request something that is "uncalled for":

It is always important to listen and support them in their quest to find what is best. You can do this without committing yourself, and then you can learn more about what it is they want. When you have attained a level of knowledge about what they are asking for, then you can have an honest conversation with them about its merits and limitations. (Rosenberg, Westling, \& McLeskey, 2011, p. 395)

\section{Social Relations/Social Justice Discourse}

With the most recent books, the signs of progress are easily found. The portraits of families drawn by recent introductory text books in special education are generally much more focused on ways to increase and improve family involvement in schools. The most recent edition of one such popular text (Turnbull, Turnbull, \& Wehmeyer, 2010) draws a picture of parents of children with disabilities as more like than unlike parents of children in general education.

Like the parents of children who are developing typically, parents of children who have various exceptionalities face challenges of family life: job changes and loss, the deaths of family members, financial problems, physical or mental illnesses, substance abuse, 
child abuse or community violence, and uncertainty about the future. They also experience many of the joys of life: graduations, job promotions, vacations, birthday parties, weddings, and births. (p. 101)

In a perfect example of what we label a "positive" version of the educational benefits approach, recent books tend to identify families as a resource to be supported and shared rather than a problem to be avoided or controlled. Speaking directly to its audience of future special educators, the authors go on to conclude that, "Whether required by federal or state policy or not, it is sound educational practice to form partnerships with the families of all your students" (Turnbull, Turnbull, \& Wehmeyer, 2010, p. 103).

However, even in the most recent texts, there is still only cautious and incomplete use of what we would label as a social justice approach. The work of Beth Harry, Maya Kalyanpur and a few others is now commonly cited in textbook discussions of issues such as disproportionality and class bias in schools. However, we found little if any discussion of social or cultural capital. Little attention is given to the difference elaborated by researchers such as Annette Lareau between family involvement in schools and family involvement with their children. While a surface acknowledgment of how the social construction of disability can influence family perceptions of how support must be provided, the "cult of expertise" that has long dominated special education culture is still allowed to bolster a deficit model where the keys are accurate assessment and "'evidence-based" intervention. As we have already mentioned, none of the most recent books sampled here navigated away from the categorical approach to disability. As such there is in these books - at their very organizational heart - an implicit endorsement in all of these texts of the status quo in special education. 


\section{Some Further Findings: Disability Variations, Messages and Marginalization}

Brantlinger was an early and persistent advocate of listening to the voice of the marginalized and devalued in society (Brantlinger, 1993; 2003; Brantlinger, Klein, \& Guskin, 1994). Her book length ethnographies provided that balance of personal detail and narrative voice along side her interpretive insight and theoretical summary. In that sense, one could argue that the vignettes and personal stories offered in the call-out sections common to more recent textbooks, is a genuine attempt to provide a more direct and personal voice of the student and the family.

However, we think that Brantlinger herself would note the mixed ideological messages that trouble us about this stylistic development. The very use of call-outs to provide information about families raises a positionality issue. Boxing off stories of the experiences of families and persons with disabilities positions them as less objective and - more personal and less important than the information in the text in the same way that students are too often boxed off in school either in separate environments or in separated spaces in typical classrooms. Still for many of these future educators reading these textbooks, this subtle message as well as the content of the call out is as much as they will be offered or learn about the experiences of families and their role in schools and they most often depict the themes presented in the text.

Similarly, the content included in the call-outs while it has changed over the years, has not shifted dramatically. In our sample, the earliest texts using call-outs date from 1997 (Kirk, Gallagher \& Anastasiow) and while not framing the having of a child with disability as a "family disaster," there is a lot of discussion and messages about family stress and how unprepared families are to parent a child with disabilities. In many of the call outs that focus on strategies for teachers, but that also mention families, there is a strong message that it is the role of school professionals to teach families to parent differently and the role of family members to listen to the expert advice of school professionals. With 
regard to emotional and behavioral disorders, there is a strong message that poverty, family violence, drug use, and parental psychological disorders are responsible for the child's behavior. Even by 2012 (Kirk, Gallagher, Coleman \& Anastasiow) not much changes. There is more emphasis on family systems and different kinds of families, but the emphasis on family stress remains and the grief/mourning motif about the loss the disabled child represents continues to be emphasized even when trying to describe how families cope and adjust. The allegorical story (Kingsley, 1987) of flying to Italy only to land in Holland gets repeated in several of even the more current texts. The "loss that will never, never go away because of the lost dreams" and that somehow the new life in Holland is "less" than the planned life and is only partly mitigated by the positive notions that one learns to appreciate and even love Holland, and presumably, the new child with a disability.

In some accounts, mothers are depicted as heroines. In other accounts, professionals are said to play the role of "bridging the gap" between family beliefs and preferences and what experts know is "best" for the child. There are also noticeable exceptions to these patterns. In Heward (2009), for example, there is a shift to emphasize partnerships and diminish the persistent power differential that often exists between school professionals and family members.

The Hallahan, et al. $(2003,2012)$ texts present a unique emphasis on special education as essential it is intensive, relentless and specific and without this approach many children would be lost to their disabilities. There is also a strong anti-inclusion message including the call out that lists 5 reasons parents offer for including their child in general education and 10 reasons parents list against such placements. This orientation is played out even in the stories about families such as Nolan, who has Down Syndrome and gets "intensive, relentless, and specific" early intervention services and in elementary school can spend only half his day in a third grade class and the rest in pull out for 
"intensive" instruction coordinated through "relentless collaboration among educators and Nolan's parents.

The most recent texts (e.g., Rosenburg, Westling, \& McLeskey, 2011 and Turnbull, Turnbull \& Wehmeyer, 2010) do reveal some more progressive depictions. Certainly there is more diversity in visual images and narratives which cover a range of situations: single parent families, families that distrust schools because of their own experiences, parents using due process to obtain adequate services, effective partnerships that benefit student learning, and so on. These more recent texts also tend to have more first person narratives from both families and youth with disabilities rather than presenting information about families and people with disabilities in a third person voice.

\section{A Concluding Summary}

It would be surprising if no substantive changes were found between works published in the 1960s and 70 s and works published in the last decade. In many cases, the changes we found have little to do with disability as such. For example, the cultural diversity of families was dealt with poorly or not at all in the early books, with issues of economic class and racial difference often troublingly conflated. For the most part, the traditional nuclear family -- both birth parents living together with children in school, father working, mother at home -- was at least implicitly assumed as the norm. Many of the recent textbooks acknowledged the diversity of family structure and composition. Indeed, as one recent textbook put it, the definition of what counts as a "family" should include any group of two or more people who both "regard themselves" as a family, and "carry out the functions" typically performed by families (Turnbull, Turnbull, \& Wehmeyer, 2010, p. 100).

In many ways, we believe that the discussion of families in these textbooks has moved forward more quickly than we had anticipated, given the market forces that govern textbook publishing. Our impression is that the discussion of families in these textbooks has evolved more quickly than the 
discussion of disability in general. There is a lot of language to point to that seems to recognize the systemic inequities faced by families who differ from the dominant discourse of our schools. The conversation about families in these texts has seemingly learned more from general education about the importance of cultural diversity and social capital than it has from disability studies about the complicated interpretation of stigma and oppression. If the portraits of families drawn by the "big glossies" have become more lifelike and multi-layered on the one hand, they remain frustratingly incomplete on the other. 


\section{References}

Apple, M. W. (1989). Teachers and texts: A political economy of class and gender relations in education. New York: Routledge.

Apple, M. W. \& Christian-Smith, L. K. (Eds.)(1991). The politics of the textbook. New York: Routledge.

Bogdan, R. C., \& Biklen, S. K. (2007). Qualitative research for education: An introduction to theories and methods ( $5^{\text {th }}$ Ed.). Boston: Allyn and Bacon.

Brantlinger, E. (1997). Using ideology: Cases of nonrecognition of the politics of research and practice in special education. Review of Educational Research, 67, 425-459.

Brantlinger, E. (2003). Dividing classes: How the middle class negotiates and rationalizes school advantage. New York: Routledge.

Brantlinger, E. (2006). The big glossies: How textbooks structure (special) education. In E. Brantlinger (Ed.), Who benefits from special education: Remediating [fixing] other people's children (pp. 45-75). Mahwah, NJ: Lawrence Erlbaum.

Brantlinger, E. A., Klein, S. M., \& Guskin, S. L. (1994). Fighting for Darla: Challenges for family care and professional responsibility. New York: Teachers College Press.

*Chinn, P. C., Drew, C. J., \& Logan, D. R. (1975). Mental retardation: A life cycle approach. St. Louis, MO: C. V. Mosby.

*Drew, C. J., Hardman, M. L., \& Logan, D. R. (1996). Intellectual disabilities across the life span (9 ${ }^{\text {th }}$ ed.). Englewood Cliffs, NJ: Merrill-Prentice Hall. 
Ferguson, C., Ramos, M., Rudo, Z., \& Wood., L. (2008). The school-family connection: Looking at the larger picture: A review of current literature. Austin, TX: Southwest Educational Development Lab. Retrieved from www.sedl.org/connections/resources/sfclitrev.pdf

Ferguson, D. L., \& Galindo, R. (2008). Improving family/school linkages through inquiry and action: Reports from sixteen schools in two states. New Hampshire of Education, XI, 66 - 75.

Ferguson, D. L., \& Ferguson, P. M. (2010, May). Family planning: Using a social justice approach to improving family/school linkages. Paper presented at the annual conference of the American Educational Research Association, Denver, CO.

Ferguson, D.L., \& Galindo, R. (2008). Improving family/school linkages through inquiry and action: Reports from 16 schools in two states. The New Hampshire Journal of Education, 11, 66-75.

Ferguson, P. M. (2008). The doubting dance: Contributions to a history of parent/professional interactions in early $20^{\text {th }}$ century America. Research and Practice for Persons with Severe Disabilities, 33, 4858.

Ferguson, P. M., \& Ferguson, D. L. (2006). Finding the "proper attitude": The potential of disability studies to reframe family/school linkages. In S. Danforth \& S. L. Gabel (Eds.), Vital questions facing disability studies in education (pp. 217-235). New York: Peter Lang.

Ferguson, P. M., Ferguson, D. L., \& Taylor, S. J. (1992). Introduction: Interpretivism and disability studies. In P. M. Ferguson, D. L. Ferguson \& S. J. Taylor (Eds.), Interpreting disability: A qualitative reader (pp. 1-11). New York: Teachers College Press.

Ferguson, D.L., Hanreddy, A. \& Ferguson, P.M. (in press). Finding a voice: Families roles in schools. In L. Florian (Ed.), Handbook on Special Education, $2^{\text {nd }}$ Ed. Thousand Oaks, CA: Sage Publications. 
*Friend, M. (2011). Special education: Contemporary perspectives for school professionals. Upper Saddle River, NJ: Pearson

Gartner, A., Lipsky, D. K., \& Turnbull, A. P. (1991). Supporting families with a child with a disability: An international outlook. Baltimore, MD: Paul Brookes.

Gonzalez, N., Moll, L. C., \& Amanti, C. (2005). Funds of knowledge: Theorizing practice in households, communities, and classrooms. Mahwah, NJ: L. Erlbaum and Associates.

Hallahan, D. P., \& Kauffman, J. M. (1978). Exceptional children: Introduction to special education. Englewood Cliffs, NJ: Prentice-Hall, Inc.

Harry, B., Kalyanpur, M., \& Day, M. (1999). Building cultural reciprocity with families: Case studies in special education. Baltimore: Paul H. Brookes Publishing Co.

Henderson, A. T., \& Mapp, K. L. (2002). A new wave of evidence: The impact of school, family and community connections on student achievement. Austin, TX: Southwest Educational Development Lab. Retrieved from www.sedl.org/connections/resources/evidence.pdf

*Heward, W. L. (2009). Exceptional children: An introduction to special education (9 ${ }^{\text {th }}$ Ed.). Upper Saddle River, NJ: Merrill Pearson

Kalayanpur, M., Harry, B., \& Skrtic, T. (2000). Equity and advocacy expectations of culturally diverse families' participation in special education. International Journal of Disability, Development and Education, 47(2), 119-136.

Kingsley, E. P. (1987). Welcome to Holland. Retrieved from http://www.ourkids.org/Archives/Holland.html 
*Kirk, S. A. (1962). Educating exceptional children. Boston: Houghton Mifflin.

${ }^{*}$ Kirk, S. A. (1972). Educating exceptional children ( $2^{\text {nd }}$ ed.). Boston: Houghton Mifflin.

*Kirk, S. A. \& Gallagher, J. J. (1979). Educating exceptional children ( $3^{\text {rd }}$ ed.). Boston: Houghton Mifflin.

*Kirk, S. A., \& Gallagher, J. J. (1989). Educating exceptional children (6 $6^{\text {th }}$ ed.). Boston: Houghton Mifflin.

Kirk, S. A., Gallagher, J. J., \& Anastasiow, N. J. (1997). Educating exceptional children ( $8^{\text {th }}$ ed.). Boston: Houghton Mifflin.

*Kirk, S. A., Gallagher, J. J., \& Coleman, M. R., \& Anastasiow, N. J. (2009). Educating exceptional children $\left(12^{\text {th }}\right.$ ed.). Florence, KY: Wadsworth.

Kohn, A., \& Shannon, P. (Eds.) (2003). Education, Inc.: Turning learning into a business. Portsmouth, NH: Heinemann.

Lareau, A. (2005). Home advantage: Social class and parental intervention in elementary education. Mahwah, NJ: L. Erlbaum Associates

Lightfoot, S. L. (2004). "Some parents just don't care": Decoding the meanings of parental involvement in urban schools. Urban Education, 39(1), 91-107.

Lopez, G. R., Scribner, J. D., \& Mahitivanichcha, K. (2001). Redefining parental involvement: Lessons from high-performing migrant-impacted schools. American Educational Research Journal, Vol. 38, No.2, 253-288.

Marshall, C. \& Rossman, G. B. (2006). Designing qualitative research ( $4^{\text {th }}$ ed.). Thousand Oaks, CA: Sage.

Moll, L. \& Greenberg, J. (1990). Creating zones of possibility: Combining social contexts for instruction. In L. Moll (Ed.), Vygotsky and Education (pp-319-348). Cambridge: Cambridge University Press. 
Rao, S. S. (2000). Perspectives of an African-American mother on parent-professional relationships in special education. Mental Retardation, 38, 473-488.

Rosenberg, M., Westling, D., \& McLeskey, J. (2011). Special education for today's teachers: An introduction ( $2^{\text {nd }}$ ed.). Boston: Pearson.

Rossman , G. B., \& Rallis, S. F. (2003). Learning in the field: An introduction to qualitative research ( $2^{\text {nd }}$ ed.). Thousand Oaks, CA: Sage.

Sands, D. J., Kozleski, E., \& French, N. (2000). Inclusive education for the $21^{\text {st }}$ century: A new introduction to special education. Belmont, CA: Wadsworth

*Smith, R. M., \& Neisworth, J. T. (1975). The exceptional child: A functional approach. New York: McGraw-Hill.

Turnbull, A., Turnbull, R., Erwin, E. J., Soodak, L. C. \& Shogren, K A. (2010). Families, professionals, and exceptionality: Positive outcomes through partnerships and trust (6th Ed). New York: Pearson.

*Turnbull, A., Turnbull, R., \& Wehmeyer, M. L. (2010). Exceptional lives: Special education in today's schools ( $6^{\text {th }}$ Ed.). Columbus, $\mathrm{OH}$ : Merrill.

\footnotetext{
i The authors would like to thank the anonymous reviewers for suggesting that this specific focus on representation of families in textbooks could be usefully expanded to family-school-community collaboration. That is the ultimate goal of our work, but exceeded the limits of space and focus for this special issue of IJIE.
} 